\title{
ACTIVE IMMUNISATION OF MICE AGAINST MUSCLE DAMAGE MEDIATED BY CANDIDA ALBICANS
}

\author{
Donna L. Oblack and I. A. HoldeR* \\ Department of Microbiology, University of Cincinnati College of Medicine and \\ *The Shriners Burns Institute, Cincinnati, Ohio, USA
}

USING an experimental murine model to examine early events in the pathogenesis of infection with Candida albicans, we described the appearance of a muscle lesion in moribund animals $12 \mathrm{~h}$ after intravenous injection of C. albicans (Oblack, Schwarz and Holder, 1978). Severe interstitial myocarditis was demonstrated histologically and markedly elevated levels of the muscle enzyme, creatine phosphokinase (CPK), were found in the sera of these animals. The tissue specificity of the CPK enzyme (Hess et al., 1964; Dawson and Fine, 1967) enable us to investigate the effect of $C$. albicans on the host with an enzyme assay as an indicator of in-vivo muscle damage.

The possible significance of muscle damage in the pathogenesis of Candida infection was realised when it was discovered that the injection of virulent strains of $C$. albicans, $C$. stellatoidea and $C$. tropicalis produced elevated serum CPK levels, whereas avirulent isolates of seven species of Candida were without effect (Oblack, Schwarz and Holder, 1979). In addition, the data suggested that damage to host tissues was restricted to sites where large numbers of Candida were present and that metabolic activity on the part of the infecting organism was required (Oblack $e t$ al., 1979).

There are few reports on the successful immunisation of animals with Candida. Increased survival of animals actively immunised with whole or disrupted cells of $C$. albicans (Mourad and Friedman, 1961; Soles, Lim and Louria, 1966; Giger, Domer and McQuitty, 1978) or C. albicans ribosomal preparations (Saunders, Solotorovsky and Tewari, 1975) have been documented. The passive transfer of immune sera has also extended the survival of animals after systemic challenge with C. albicans (Mourad and Friedman, 1968; Al-Doory, 1970).

The present paper reports investigations on active immunisation of mice with viable, nonviable, and disrupted cells of $C$. albicans and the effects of these treatments on survival and muscle damage after subsequent intravenous challenge with $C$. albicans.

\section{MATERIALS AND METHODS}

Animals. Female, outbred Swiss mice, strain CD-1 (Charles River) weighing 22-24 g were used in all experiments.

Organisms. Candida albicans strain CA2 was obtained from the Mycology Laboratory of the Cincinnati General Hospital. The LD50 for this yeast was found to be $3 \times 10^{5}$ colony-forming units (c.f.u.) (Oblack et al., 1979). Candida albicans strain CA526 was kindly provided by Dr. H. F. Hasenclever, Hamilton, Montana. Because intravenous (i.v.) injection of mice with $10^{7}$ c.f.u. of this organism produced no mortalities in 21 days (Oblack et al. 1979) this strain was considered avirulent.

Active immunisation of mice. Vaccines of viable C. albicans strain CA2 or cells disrupted with a Mickle Disintegrator (Brinkmann Instruments, Des Plaines, Illinois) were prepared by the method of Mourad and Friedman (1961). In addition, a third vaccine of heat-killed cells $\left(100^{\circ} \mathrm{C}, 15 \mathrm{~min}\right.$.) was similarly prepared. Animals were immunised with $0.2 \mathrm{ml}$ of the respective vaccines, according to the schedule of Mourad and Friedman (1961) and were challenged on the

Received 20 April 1979; accepted 15 May 1979.

Requests for reprints should be sent to Dr I. A. Holder, The Shriners Burns Institute, 202 Goodman Street, Cincinnati, Ohio 45219, USA.

J. MED. MICROBIOL. - VOL. 12 (1979) 
day after the last immunisation with 1 LD50 C. albicans strain CA2. For comparative purposes, a disrupted cell vaccine from the avirulent $C$. albicans strain CA526 was used to immunise animals before challenge with $C$. albicans strain CA2 in one experiment.

Survival of immunised mice. Groups of 14-15 mice immunised with the respective Candida vaccines and a control group of animals given injections of saline were examined daily for 28 days after i.v. injection of C. albicans, and the number of deaths was recorded.

Enzyme assay. Animals were anaesthetised with methoxyflurane (Metofane, PitmanMoore, Washinton Crossing, New Jersey) and bled by cardiac puncture. Individual sera were tested within $3 \mathrm{~h}$ for CPK activity as previously described (Oblack et al., 1979) or frozen at $-20^{\circ} \mathrm{C}$ and tested within $48 \mathrm{~h}$.

Counts of C. albicans in cardiac tissue. Hearts were aseptically excised from animals $12 \mathrm{~h}$ after the i.v. injection of $C$. albicans and the number of c.f.u. was determined by the method of Saymen $e t$ al. (1972). Data were expressed as the $\log _{10}$ of the number of c.f.u. per g. (wet weight) of tissue.

\section{RESULTS}

\section{Muscle damage in immunised mice}

Groups of mice were immunised with vaccines of viable, heat-killed or disrupted cells of $C$. albicans before challenge with 1 LD50 of the homologous organism. Previous experiments had established that the serum CPK levels of uninfected mice ranged from 100 to $400 \mathrm{IU} /$ litre (Oblack et al., 1979). Twelve hours after challenge with 1 LD50 C. albicans, serum CPK levels of the control mice were over $1400 \mathrm{IU} /$ litre (table I). However, elevated serum CPK levels were not found in animals immunised with Candida vaccines of either viable, nonviable, or disrupted cells. It is noteworthy that animals immunised with a vaccine of disrupted cells from an avirulent strain of $C$. albicans were not protected against the muscle-damaging effects of $C$. albicans.

TABLE I

Serum creatine phosphokinase levels of immunised mice $12 \mathrm{~h}$ after intravenous challenge with ILD50 of Candida albicans

\begin{tabular}{l|c}
\hline \multicolumn{1}{c|}{ Immunogen } & $\begin{array}{c}\text { Serum creatine phosphokinase } \\
\text { (IU/litre) }\end{array}$ \\
\hline C. albicans, disrupted & $274 \pm 81^{*}$ \\
C. albicans, viable & $563 \pm 102$ \\
C. albicans, nonviable & $378 \pm 66$ \\
C. albicans (avirulent), disrupted & $1408 \pm 179$ \\
Saline & $1436 \pm 172$ \\
\hline
\end{tabular}

* Data are expressed as the mean \pm the standard error of the mean (SEM) of five animals.

\section{Numbers of C. albicans in cardiac tissue}

The amount of the CPK enzyme released into serum after muscle injury was shown to be directly related to the challenge dose of C. albicans (Oblack, et al., 1979). To determine whether protection against muscle damage in the immunised mice was related to a reduced number of organisms in the tissue, the c.f.u. of C. albicans were enumerated in samples of cardiac tissue collected $12 \mathrm{~h}$ after i.v. injection of the challenge dose. These data are presented in table II. Twelve hours after Candida challenge, the number of c.f.u. of $C$. albicans found in the cardiac tissue of mice immunised with Candida vaccines was similar to the number found in the control animals.

\section{Survival of immunised mice after challenge}

The previous data (table I) which indicated that immunisation with the Candida vaccines 
TABLE II

Numbers of yeast cells recovered from the hearts of immunised mice $12 \mathrm{~h}$ after intravenous challenge with 1 LD50 of C. albicans

\begin{tabular}{l|c}
\hline \multicolumn{1}{c|}{ Immunogen } & $\begin{array}{c}\left.\text { Number ( } \log _{10}\right) \text { of colony-forming } \\
\text { units of Candida per g of heart }\end{array}$ \\
\hline C. albicans, disrupted & $4 \cdot 19 \pm 0.04^{*}$ \\
C. albicans, viable & $3.96 \pm 0.07$ \\
C. albicans, nonviable & $3.98 \pm 0.04$ \\
Saline & $4 \cdot 26 \pm 0.09$ \\
\hline
\end{tabular}

* Data are expressed as the mean \pm SEM of five animals.

protected mice against early events during Candida infection prompted an examination of the effects of immunisation on survival of mice over an extended interval. After intravenous challenge with $1 \mathrm{LD} 50$ of $C$. albicans, the control mice began dying in the second post-challenge week and only $20 \%$ of the animals survived for 4 weeks (table III). However, immunisation with the Candida vaccines provided substantial protection as evidenced by the $86-100 \%$ survival of immunised mice for 28 days.

TABLE III

Survival of immunised mice after intravenous challenge with 1 LD50 of Candida albicans

\begin{tabular}{l|rrrr}
\hline \multirow{2}{*}{ Immunogen } & \multicolumn{4}{c}{ Percent* survival at week } \\
\cline { 2 - 5 } & 1 & 2 & 3 & 4 \\
\hline C. albicans, disrupted & 100 & 100 & 100 & 100 \\
C. albicans, viable & 100 & 100 & 93 & 86 \\
C. albicans, nonviable & 100 & 100 & 87 & 87 \\
Saline & 100 & 73 & 47 & 20 \\
\hline
\end{tabular}

* Of 14-15 mice in each group.

Discussion

Successful (Mourad and Friedman, 1961; Hasenclever and Mitchell, 1963; Soles et al., 1966; Giger et al., 1978) and unsuccessful (Hurd and Drake, 1953; Winner, 1956) attempts at active immunisation of animals against $C$. albicans infections have been reported. In these investigations, protection was assessed by the survival of immunised animals after varying challenge doses of C. albicans. It was our intention to examine the effects of immunisation upon an event that occurs early in the pathogenesis of Candida infection, that is, a muscle lesion as evidenced by elevated levels of the CPK enzyme in serum. The results (table I) indicate that animals could be protected against muscle injury by active immunisation with vaccines prepared from viable, nonviable, or disrupted $C$. albicans. It was further shown that, in addition to protection against early tissue injury, immunisation was also effective in extending survival after Candida challenge (table III); these data confirm the previous observation made by Mourad and Friedman (1961).

The nature of the immunity that we observed in these experiments remains to be elucidated. The role of humoral immunity in resistance to systemic C. albicans infection has been implicated by the transfer of immunity to recipients by immune sera (Mourad and Friedman, 1968; Al-Doory, 1970). In addition, the passive transfer of immune sera also protected mice against a localised thigh lesion (Pearsall, Adams and Bunni, 1978). On the other hand, cellular immunity was not required for defence against systemic candidiasis (Rogers, Balish and Manning, 1976) or localised candidiasis (Pearsall et al., 1978). An increase in humoral immunity associated with opsonising antibodies, and enhanced fungicidal activity of the host defence cells through an increase in cellular immunity would have been reflected in a decrease in the numbers of Candida 
cells in the tissues. However, protection against muscle injury occurred in the absence of reduced tissue counts of Candida (table II). These data imply the possibility of humoral immunity directed against a muscle-damaging factor elaborated by C.albicans. While it is still unknown whether immunity occurred through the same mechanism in animals immunised with different Candida vaccines, if a common mechanism is subsequently shown to exist, the present data suggest that an effective endogenous immunogen is present in virulent $C$. albicans, is absent from avirulent $C$. albicans, and is heat stable.

\section{SUMMARY}

The effect of active immunisation on muscle damage after systemic infection with Candida albicans was examined in a murine model. Mice were successfully immunised against acute muscle damage by vaccines of viable, nonviable, or disrupted C. albicans. In addition, markedly enhanced survival of immunised mice was demonstrated over a 4-week interval. There was protection against muscle damage in immunised mice without a reduction in the number of organisms present in cardiac tissue. The data indirectly implicate the role of humoral immunity in the protection afforded by immunisation.

\section{REFERENCES}

AL-DOORY, Y. 1970. An immune factor in baboon anti-Candida serum. Sabouraudia , 8, 41.

Dawson, D. M. AND Fine, I. H. 1967. Creatine kinase in human tissues. Archs Neurol., 16, 175.

Giger, D. K., Domer, J. E. AND MCQuitTy, J. T. 1978. Experimental murine candidiasis: pathological and immune responses to cutaneous inoculation with Candida albicans. Infect. Immun., 19, 499.

Hasenclever, H. F. AND Mitchell, W. O. 1963. Acquired immunity to candidiasis in mice. $J$. Bact. 86, 401.

Hess, J. W., MacDonald, R. P., Frederick, R. J., Jones, R. N., Neely, J. and Gross, D. 1964. Serum creatine phosphokinase (CPK) activity in disorders of heart and skeletal muscle. Ann. intern. Med., 61, 1015.

HuRD, R.C. AND DRAKE, C.H. 1953. Candida albicans infections in actively and passively immunized animals. Mycopathologia, 6, 290.

MOURAD, S. AND FRIEDMAN, L. 1961. Active immunization of mice against Candida albicans. Proc. Soc. exp. Biol. Med., 106, 570.

Mourad, S. AND Friedman, L. 1968. Passive immunization of mice against Candida albicans. Sabouraudia, 6, 103.

Oblack, D., SChWARz, J. AND Holder, I. A. 1978. Biochemical examination of sera during systemic Candida infection in mice. Infect. Immun., 19, 992.

Oblack, D., SchwartZ, J. AND Holder, I. A. 1979. In vivo muscle damage during Candida infection. Sabouraudia, in press.

Pearsall, N. N., Adams, B. L. AND BunNi, R. 1978. Immunologic responses to Candida albicans. III. Effects of passive transfer of lymphoid cells or serum on murine candidiasis. J. Immunol., 120, 1176.

Rogers, T. J., Balish, E. AND Manning, D. D. 1976. The role of thymus-dependent cellmediated immunity in resistance to experimental disseminated candidiasis. J. reticuloendothel. Soc., 20, 291.

SAUNDERS, E. S., Solotorovsky, M. AND TeWARI, R. P. 1975. Immunization against experimental candidosis with ribosomal preparations from Candida albicans. Abst. ann. Mtg. Amer. Soc. Microbiol., F22, p. 89.

Saymen, D. G., Nathan, P., Holder, I. A., Hill, E. O. and MacMillan, B. G. 1972. Infected surface wound: an experimental model and a method for the quantitation of bacteria in infected tissues. Appl. Microbiol., 23, 509.

Soles, P., Lim, L.Y. AND LouRIA, D.B. 1966. Active immunity in experimental candidiasis in mice. Sabouraudia 5, 315.

WiNNER, H. I. 1956. Immunity in experimental moniliasis. J. Path. Bact. 71, 234. 